\title{
Analisa Kualitas Tanah Pada Berbagai Penggunaan Lahan di Sub Sub DAS Cimanuk Hulu
}

\section{Nurina Hanum Ayuningtias'), Mahfud Arifin²) dan Maya Damayani2)}

1) Alumni Program Studi Pascasarjana Ilmu Tanah Fakultas Pertanian Universitas Padjadjaran

2)Staff Pengajar Departemen Ilmu Tanah dan Sumberdaya Lahan Fakultas Pertanian

Universitas Padjadjaran, Jl. Raya Bandung Sumedang Km 21 Jatinangor

Korespondensi: nurina1811@gmail.com

\begin{abstract}
Soil quality test is needed to find out the influence of landuse change due to soil quality dan characteristics. This research aims to comparing various land use that influence the physical, chemical and biological soil on Andisol and Inceptisol, obtain information of soil quality at various land uses on Andisol and Inceptisol, and study the relationship between soil quality and erosion at various land use The study was conducted in Sub Sub watershed Hulu Cimanuk with an area of 16.171 hectares. The study was conducted on four different types of land use namely forest land, agriculture land, tea garden and mixed garden. The study was conducted with survey methods, descriptive and comparative. Erosion calculation using the RUSLE formula.Analysis of soil quality is calculated based on criteria Mausbach \& Seybold (1998) and modified in accordance with the conditions of the study area. The results showed that each land use has a different effect on soils quality nor with erosion. Soil quality on forest land has higher value than other land use and erosion that occurs most low at 0.2 tonnes / ha / year. The use of dry land has the lowest value of soil erosion begitupula highest of 387 tonnes / ha / year.
\end{abstract}

Key words: erosion, landuse change, soil quality, and watershed.

\section{PENDAHULUAN}

Berdasarkan UU No. 7/2004 tentang sumberdaya air, DAS adalah suatu wilayah daratan yang merupakan satu kesatuan dengan sungai dan anak-anak sungainya yang berfungsi menampung, menyimpan dan mengalirkan air yang berasal dari curah hujan ke danau atau laut secara alami. Batasan DAS di darat merupakan pemisah topografi, sedangkan di laut sampai de-ngan daerah perairan yang masih terpengaruh aktivitas daratan.

Daerah Aliran Sungai Cimanuk merupakan salah satu dari 42 DAS di Indonesia yang tergolong dalam DAS kritis. Menurut Balai Data dan Informasi Sumberdaya Air Dinas Pengelolaan Sumberdaya Air Jawa Barat, kondisi lahan kritis di DAS Cimanuk, dari hulu hingga hilir mencapai 40.875 hektar atau sebesar $27,98 \%$ dari daerah tangkapan airnya. Luas lahan kritis terbesar berada di Kabupaten Garut yang telah mencapai 30.442 ha.
Berdasarkan data penggunaan lahan tahun 1999 sampai 2011 di DAS Cimanuk Hulu menunjukkan bahwa luas penggunaan lahan hutan, pertanian dan pemukiman mengalami perubahan. Penggunaan lahan hutan pada tahun 1999 adalah 32.928 Ha dan pada tahun 2011 menurun menjadi 29.644 Ha. Luas lahan pertanian pada tahun 1999 adalah 99.503 Ha dan pada tahun 2011 adalah 102.383 Ha. Luas lahan pemukiman pada tahun 1999 adalah 12.634 Ha dan pada tahun 2011 adalah 13.037 Ha (Rahasiani, 2014).

Berdasarkan gambaran perubahan lahan tersebut dapat di hubungkan bahwa faktor tingkat pertumbuhan penduduk dan ekonomi sosial masyarakat yang tidak teratur. Hal ini berpengaruh kepada peningkatan kebutuhan sandang, pangan dan papan harus terpenuhi dimana seseorang tinggal. Peningkatan kebutuhan tersebut berakibat pada pembukaan lahan baru menuju daerah perbukitan dan 
pegunungan. Kebutuhan papan yang harus terpenuhi menyebabkan lahan pertanian beralih fungsi menjadi kawasan pemukiman dan saat kebutuhan pangan yang harus terpenuhi maka hutan yang akan beralih fungsi menjadi lahan pertanian.

Menurut Anwar (1990) pertumbuhan ekonomi disuatu wilayah akan mempengaruhi penggunaan lahan. Saat suatu ekosistem mulai terganggu maka dampak yang dapat terlihat adalah tingginya aliran permukaan pada daerah hulu dan sedimentasi pada daerah hilir serta fluktuasi debit air sungai yang tinggi antara musim kemarau dan musim hujan. Kegiatan destruksi pada wilayah hulu yaitu erosi dan pengikisan tanah telah menimbulkan lahan kritis. Air hujan yang jatuh menumbuk tanah yang tidak cukup terlindung oleh kanopi akan menghancurkan agregat tanah yang menyebabkan tanah tersebut peka terhadap erosi.

Evaluasi terhadap kondisi dan kualitas tanah perlu dilakukan secara berkala. Tanah merupakan media tumbuhnya tanaman darat, perubahan kualitas tanah akan mempengaruhi produktivitas tanaman yang tumbuh diatasnya. Aspek lain yang harus dipertimbangkan adalah kegiatan budidaya pertanian baik di dataran rendah ataupun tinggi yang berpotensi menyebabkan kekritisan lahan. Pada akhirnya, hal ini akan berpengaruh terhadap ketahanan pangan. Kelestarian lingkungan dan kesinambungan pertanian harus dipertahankan guna mempertahankan ketahanan pangan. Tolak ukur yang menggambarkan kecenderungan kondisi dan kualitas tanah sangat diperlukan dalam hal monitoring kualitas tanah.

Kualitas tanah merupakan gambaran terhadap respon peningkatan penekanan penggunaan lahan berkelanjutan dengan fokus holistik yang menekankan bahwa pengelolaan tanah berkelanjutan membutuhkan lebih dari sekedar pengendalian terhadap erosi (Karlen, 1996). Kualitas tanah menggambarkan kesesuaian sifat-sifat fisik, kimia dan biologi tanah yang secara bersama-sama berfungsi sebagai: media untuk pertumbuhan tanaman dan aktivitas biologi, pengatur dan pembagi aliran air dan penyimpanannya dalam lingkungan, dan penyangga lingkungan dari perusakan oleh senyawa berbahaya (Larson and Piece, 1994 dalam Wulaningsih, 2008).

Penelitian kualitas tanah ini menekankan bahwa sumberdaya tanah ditentukan oleh dua faktor yaitu tanah dan faktor pembentukannya serta manajemen pengelolaan tanah yang dilakukan oleh manusia. Kualitas tanah diukur berdasarkan pengamatan sifat kimia, fisika dan biologi serta interaksinya.

\section{BAHAN DAN METODE}

\subsection{Waktu dan Tempat Penelitian}

Penelitian ini dilaksanakan selama empat bulan dari bulan Agustus sampai November 2014. Penelitian dilaksanakan di Sub Sub DAS Cimanuk hulu, Kabupaten Garut, dengan luas wilayah $16.171 \mathrm{Ha}$. Ketinggian tempat berada pada $1.000-1.700 \mathrm{~m} \mathrm{dpl}$.

\subsection{Rancangan Variabel}

Penelitian ini dilakukan menggunakan metode survey, deskriptif, komparatif dan korelasional. Metode survey yang digunakan berdasarkan pendekatan fisiografi dengan satuan pengamatan satuan lahan. Pengambilan contoh tanah dilakukan dengan metode stratified purposive sampling berdasarkan satuan lahan.

Pengamatan di lakukan pada macam tanah Typic Hapludands dengan 4 (empat) macam penggunaan lahan yaitu lahan hutan, tegalan, kebun campuran dan kebun teh. Pengamatan sampel tanah di lakukan pada 12 titik pengamatan, dimana setiap jenis penggunaan lahan di lakukan pengulangan sebanyak tiga kali. Pengulangan dilakukan bertujuan untuk meningkatkan ketelitian atau mengatasi satuan percobaan yang kurang homogen.

Variabel yang diamati dalam penelitian ini adalah sifat fisik, kimia dan biologi tanah. Pengaruh penggunaan lahan terhadap sifat fi- 
sik, kimia dan biologi tanah dapat dilihat dengan menggunakan analisis sidik ragam dua arah yang kemudian dilakukan uji lanjut Duncan.

\subsection{Analisis Indeks Kualitas Tanah}

Parameter-parameter sifat fisik, kimia dan biologi tanah tersebut termasuk dalam indeks kualitas tanah. Penilaian kualitas tanah dilakukan dengan pendekatan indeks kualitas tanah yang dihitung berdasarkan nilai dan bobot tiap indikator kualitas tanah. Kriteria penilaian indeks kualitas tanah di sajikan pada Tabel 1. Cara perhitungan indeks dapat dijelaskan sebagai berikut: a. Indeks bobot dihitung dengan mengalikan bobot fungsi tanah (bobot 1) dengan bobot medium perakaran (bobot 2) dan bobot kedalaman perakaran (bobot 3).

b. Skor dihitung dengan membandingkan data pengamatan dari indikator tanah dan fungsi penilaian. Skor berkisar dari 0 (buruk) sampai 1 (baik). Penetapan skor dapat melalui interpolasi atau persamaan linier sesuai dengan kisaran yang ditetapkan berdasar harkat atau berdasarkan data yang diperoleh.

c. Indeks kualitas tanah dihitung dengan mengalikan indeks bobot dan skor dari indikator.

Tabel 1 Kriteria Penilaian Indeks Kualitas Tanah Andisol

\begin{tabular}{|c|c|c|c|c|c|c|c|c|c|}
\hline \multirow{2}{*}{$\begin{array}{l}\text { Fungsi } \\
\text { tanah }\end{array}$} & \multirow{2}{*}{$\begin{array}{l}\text { Bobot } \\
\text { (1) }\end{array}$} & \multirow[t]{2}{*}{ Indikator tanah } & \multirow{2}{*}{$\begin{array}{l}\text { Bobot } \\
(2)\end{array}$} & \multirow{2}{*}{$\begin{array}{c}\text { Bobot } \\
\text { (3) }\end{array}$} & \multirow{2}{*}{$\begin{array}{l}\text { Index } \\
\text { bobot }\end{array}$} & \multicolumn{2}{|c|}{$\begin{array}{l}\text { Batas } \\
\text { bawah }\end{array}$} & \multicolumn{2}{|c|}{ Batas atas } \\
\hline & & & & & & $\mathrm{X} 1$ & Y1 & $\mathrm{X} 2$ & $\mathrm{Y} 2$ \\
\hline \multirow[t]{12}{*}{$\begin{array}{l}\text { Melestarikan } \\
\text { aktivitas } \\
\text { biologi }\end{array}$} & 0,4 & $\begin{array}{l}\text { Medium perakaran } \\
\text { - Kedalaman } \\
\text { perakaran }(\mathrm{cm})\end{array}$ & 0,33 & 0,6 & 0,079 & 10 & 0 & 60 & 1 \\
\hline & & $\begin{array}{l}\text { - Berat volume (g/ } \\
\left.\mathrm{cm}^{3}\right)\end{array}$ & & 0,4 & 0,053 & 0,38 & 0 & 0,87 & 1 \\
\hline & & Kelengasan & 0,33 & & & & & & \\
\hline & & - Porositas (\%) & & 0,2 & 0,027 & 67,19 & 0 & 85,59 & 1 \\
\hline & & - C-organik (\%) & & 0,4 & 0,050 & 1,48 & 0 & 8,49 & 1 \\
\hline & & - Debu+lempung (\%) & & 0,4 & 0,053 & 40,2 & 0 & 62,7 & 1 \\
\hline & & Keharaan & 0,33 & & & & & & \\
\hline & & $-\mathrm{pH}$ & & 0,2 & 0,013 & 3,93 & 0 & 6,15 & 1 \\
\hline & & - P-tersedia (ppm) & & 0,2 & 0,027 & 0,01 & 0 & 0,38 & 1 \\
\hline & & - K-tersedia $(\mathrm{cmol} / \mathrm{kg})$ & & 0,2 & 0,027 & 0,17 & 0 & 2,61 & 1 \\
\hline & & - C-organik (\%) & & 0,2 & 0,040 & 1,48 & 0 & 8,49 & 1 \\
\hline & & - N-total (\%) & & 0,2 & 0,027 & 0,56 & 0 & 4,08 & 1 \\
\hline \multirow{3}{*}{$\begin{array}{l}\text { Pengaturan } \\
\text { dan penya- } \\
\text { luran air }\end{array}$} & 0,3 & Debu + lempung (\%) & 0,6 & & 0,18 & 40,2 & 0 & 62,7 & 1 \\
\hline & & Porositas (\%) & 0,2 & & 0,06 & 67,19 & 0 & 85,59 & 1 \\
\hline & & Berat volume $\left(\mathrm{g} / \mathrm{cm}^{3}\right)$ & 0,2 & & 0,06 & 0,38 & 0 & 0,87 & 1 \\
\hline Filter dan & 0,3 & Debu+lempung (\%) & 0,6 & & 0,18 & 40,2 & 0 & 62,78 & 1 \\
\hline \multirow[t]{5}{*}{ Buffering } & & Porositas (\%) & 0,1 & & 0,03 & 67,19 & 0 & 85,59 & 1 \\
\hline & & Proses mikrobiologis & 0,3 & & & & & & \\
\hline & & - C-organik (\%) & & 0,33 & 0,029 & 1,48 & 0 & 8,49 & 1 \\
\hline & & $\begin{array}{l}\text { - Total bakteri (cfu/ } \\
\text { ml) }\end{array}$ & & 0,33 & 0,029 & 43,5 & 0 & 1.000 & 1 \\
\hline & & $\begin{array}{l}\text { - Respirasi mikroba } \\
\text { (mg/hari/100g) }\end{array}$ & & 0,33 & 0,029 & 24 & 0 & 240 & 1 \\
\hline
\end{tabular}

Sumber: Pratoyo (2005

\subsection{Analisis Erosi}

Prediksi tingkat bahaya erosi pada penelitian ini dihitung dengan menggunakan persamaan Revised Universal Soil Loss Equation
(Wischmeier and Smith, 1978). Persamaan ini merupakan pembangunan dari model USLE yang juga merupakan model empiris untuk memprediksi erosi yang dihubungkan dengan 
aliran permukaan pada suatu lahan. Model persamaan RUSLE masih mempertahankan struktur persamaan USLE, model persamaan RUSLE adalah sebagai berikut:

$$
\mathrm{A}=\mathrm{R} \times \mathrm{K} \times \mathrm{LS} \times \mathrm{C} \times \mathrm{P}
$$

Dimana:
A : banyaknya tanah tererosi dalam (ton/ha/th)
R : faktor curah hujan dan aliran permukaan
$\mathrm{K}$ : faktor erodibilitas tanah
LS : faktor panjang dan kemiringan lereng
C : faktor vegetasi penutup tanah dan pengelolaan tanaman
P : faktor tindakan-tindakan khusus konservasi tanah

\section{HASIL DAN PEMBAHASAN}

\subsection{Pengaruh Penggunaan Lahan Terhadap Sifat-sifat Tanah}

Perbedaan tutupan lahan memberikan nilai dan pengaruh yang berbeda terhadap sifat fisik, kimia dan biologi tanah. Pengaruh tutupan lahan terhadap sifat fisik, kimia dan biologi tanah disajikkan pada Tabel 2 .

Berdasarkan Tabel 2, penggunaan lahan yang berbeda memberikan pengaruh yang berbeda terhadap sifat fisik, kimia dan biologi tanah. Perubahan sifat tanah secara fisik akibat penggunaan lahan yang lebih intensif ditunjukkan dengan struktur tanah menjadi lebih padat serta berkurangnya pori makro dan pori meso. Hal tersebut berdampak terhadap kapasitas infiltrasi dan daya simpan air.

Penggunaan lahan hutan memberikan pengaruh nyata terhadap sifat fisik tanah seperti kadar air, permeabilitas, dan porositas. Lahan hutan merupakan kontrol terhadap penggunaanlahan yang lainnya. Hal tersebut menunjukkan bahwa lahan hutan memiliki nilai sifat fisik yang lebih baik dibandingkan penggunaan lahan lainnya. Semakin rapat vegetasi dan semakin sedikit pengaruh campur tangan manusia dalam hal pengolahan lahan maka akan semakin baik sifat fisik tanah tersebut.

Tabel 2 Nilai Sifat Fisik, Kimia, dan Biologi Tanah Pada Berbagai Penggunaan Lahan di Sub Sub DAS Hulu Cimanuk

\begin{tabular}{|c|c|c|c|c|c|c|c|c|c|c|c|c|c|}
\hline $\begin{array}{c}\text { Tutupan } \\
\text { Lahan }\end{array}$ & $\begin{array}{c}\text { Kadar } \\
\text { air } \\
(\%)\end{array}$ & $\begin{array}{c}\text { Bobot } \\
\text { isi } \\
(\mathrm{gr} / \\
\left.\mathrm{cm}^{3}\right)\end{array}$ & $\begin{array}{c}\begin{array}{c}\text { Perme- } \\
\text { abilitas } \\
(\mathrm{cm} / \\
\text { jam })\end{array}\end{array}$ & $\begin{array}{l}\text { Poro- } \\
\text { sitas } \\
(\%)\end{array}$ & $\begin{array}{c}\% \\
\text { Debu } \\
+ \text { liat }\end{array}$ & $\begin{array}{c}\text { Keda- } \\
\text { laman } \\
\text { Pera- } \\
\text { karan } \\
(\mathrm{cm})\end{array}$ & $\mathrm{pH}$ & $\begin{array}{c}\text { C-or- } \\
\text { ganik } \\
(\%)\end{array}$ & $\begin{array}{l}\mathrm{N}- \\
\text { total } \\
(\%)\end{array}$ & $\begin{array}{c}\text { P- } \\
\text { terse- } \\
\text { dia } \\
(\mathrm{ppm})\end{array}$ & $\begin{array}{c}\mathrm{K}- \\
\text { ter- } \\
\text { sedia } \\
(\mathrm{cmol} \\
/ \mathrm{kg})\end{array}$ & $\begin{array}{c}\text { Total } \\
\text { bakte- } \\
\text { ri } \\
(\mathrm{cfu} / \\
\mathrm{ml})\end{array}$ & $\begin{array}{l}\text { Res- } \\
\text { pirasi } \\
\text { (mg/ } \\
\text { hari/ } \\
100 \mathrm{~g})\end{array}$ \\
\hline Hutan & $79,49 \mathrm{~b}$ & $0,53 \mathrm{a}$ & $23,75 \mathrm{~b}$ & $82,74 \mathrm{~b}$ & $47,90 \mathrm{a}$ & $30 \mathrm{a}$ & $5,22 \mathrm{a}$ & $8,26 \mathrm{~b}$ & $1,01 \mathrm{~b}$ & $0,14 \mathrm{a}$ & $0,94 \mathrm{~b}$ & $5,91 \mathrm{~b}$ & $104 b$ \\
\hline Tegalan & $75,76 \mathrm{ab}$ & $0,79 \mathrm{~b}$ & $9,76 \mathrm{a}$ & $70,61 \mathrm{a}$ & $61,26 \mathrm{~b}$ & $20 \mathrm{~b}$ & $5,37 \mathrm{a}$ & $2,97 \mathrm{a}$ & $0,76 \mathrm{a}$ & $0,15 \mathrm{a}$ & $0,68 a b$ & $0,78 \mathrm{a}$ & $48 \mathrm{a}$ \\
\hline $\begin{array}{l}\text { Kebun } \\
\text { Teh }\end{array}$ & $44,82 \mathrm{a}$ & $0,61 \mathrm{a}$ & $9,78 \mathrm{a}$ & $78,25 \mathrm{ab}$ & $50,20 \mathrm{a}$ & $30 \mathrm{a}$ & $5,74 \mathrm{a}$ & $4,07 \mathrm{a}$ & $0,92 \mathrm{ab}$ & $0,02 \mathrm{~b}$ & $0,39 a b$ & $2,56 \mathrm{ab}$ & 48 \\
\hline $\begin{array}{l}\text { Kebun } \\
\text { Campur } \\
\text { an }\end{array}$ & $63,83 \mathrm{ab}$ & $0,57 \mathrm{a}$ & $\begin{array}{r}10,08 \\
a b\end{array}$ & $79,96 \mathrm{ab}$ & $48,30 \mathrm{a}$ & $30 \mathrm{a}$ & $5,55 \mathrm{a}$ & $6,10 \mathrm{ab}$ & $0,75 \mathrm{ab}$ & $0,05 \mathrm{a}$ & $0,35 \mathrm{a}$ & $3,84 \mathrm{ab}$ & $96 \mathrm{ab}$ \\
\hline
\end{tabular}

Keterangan : Angka-angka yang diikuti huruf yang sama menunjukkan tidak berbeda nyata dan angka-angka yang diikuti huruf yang berbeda menunjukan berbeda nyata menurut uji Duncan pada taraf kepercayaan $95 \%$.

Sifat kimia tanah pada setiap penggunaan lahan memberikan pengaruh yang berbeda, hal tersebut juga berkaitan dengan jenis vegetasi dan pengolahan lahan. Setiap penggunaan lahan tidak memberikan pengaruh nyata terhadap $\mathrm{pH}$ tanah. Nilai $\mathrm{pH}$ masam pada tanah Andisol menandakan tingginya curah hujan dan bahan induk yang bersifat andesitik. Pengolahan tanah dan juga pemupukan tidak memberikan pengaruh yang sig- 
nifikan terhadap peningkatan $\mathrm{pH}$ walaupun dapat dilihat bahwa terjadi peningkatan $\mathrm{pH}$ pada penggunaan lahan kebun teh.

Penggunaan lahan hutan menunjukan pengaruh yang nyata terhadap $\mathrm{C}$-organik, $\mathrm{N}$-total dan K-tersedia. Kandungan C-organik pada lahan hutan lebih tinggi dibandingkan penggunaan lahan lainnya dikarenakan tingginya variasi vegetasi dan serasah yang menyumbang bahan organik lebih banyak di bandingkan penggunaan lahan lainnya. Siklus $\mathrm{N}$ di lahan hutan merupakan siklus tertutup antara tanah, tumbuhan dan mikroorganisme, kondisi tersebut merupakan kondisi ideal ketersediaan Nitrogen di dalam tanah.

Nilai $\mathrm{K}$ tersedia pada lahan hutan tergolong tinggi sedangkan pada kebun teh rendah. Hal tersebut seiring dengan nilai $\mathrm{pH}$ pada masing-masing penggunaan lahan dimana nilai $\mathrm{pH}$ lahan hutan lebih rendah dibandingkan kebun campuran. Nilai pH memilik hubungan negatif dengan ketersediaan $\mathrm{K}$ yaitu saat $\mathrm{pH}$ naik maka konsentrasi $\mathrm{K}$ akan menurun. Tanah Andisol memiliki kandungan mineral muskovit yang banyak mengandung $\mathrm{K}$ dan $\mathrm{Mg}$ (Shoji, 1993).

Kandungan P-tersedia pada lahan hutan lebih rendah dibandingkan penggunaan lahan lainnya. Hal tersebut dikarenakan jerapan fosfat yang sangat kuat oleh mineral liat nonkristalin alofan, imogolit dan ferihidrit sehingga sangat sedikit tersedia bagi tanaman. Mineral alofan mampu meretensi $\mathrm{P}$ hingga 97,8 \%, dan keberadaan $\mathrm{Al}$ dan $\mathrm{Fe}$ dalam bentuk amorf juga mempunyai kemampuan dalam mengikat P (Sukarman dan Dariah, 2014). Pada lahan kebun teh kandunga Ptersedia lebih besar di bandingkan lahan lainnya. Hal tersebut diduga akibat pemberian bahan organik serta pemupukan dapat menurunkan retensi $P$.

Nilai total bakteri pada penggunaan lahan hutan dan tegalan memberikan pengaruh yang berbeda nyata terhadap nilai total bakteri. Hal tersebut sesuai dengan kandungan bahan orhganik pada kedua tutupan lahan tersebut. Penggunaan lahan hutan dengan kondisi alami memiliki kandungan bahan organik yang lebih tinggi dibandingkan lahan tegalan dimana lahan tersebut dalam kondisi cenderung terbuka dan sedikit vegetasi pelindung tanah. Tingginya populasi mikroorganisme merupakan salah satu pertanda tingkat kesuburan tanah. Mikroorganisme dapat tumbuh dan berkembang dengan baik hanya jika kondisi lingkungan tempat tumbuh mikroorganisme tersebut sesuai.

Penggunaan lahan hutan dan tegalan memberikan pengaruh nyata terhadap respirasi bakteri. Perbedaan vegetasi penutup tanah akan mempengaruhi sifat fisik, kimia dan biologi tanah, sehingga variasi tutupan lahan secara umum mampu merubah sifatsifat tanah. Perubahan sifat-sifat tanah tersebut secara langsung akan berpengaruh terhadap jumlah dan aktivitas mikroorganisme.

Respirasi tanah merupakan pencerminan populasi dan aktivitas mikroba tanah. Apabila dekomposisi bahan organik meningkat, maka akan meningkatkan aktivitas mikroorganisme serta dapat meningkatkan respirasi tanah. Semakin banyak $\mathrm{CO}_{2}$ yang dikeluarkan tanah, semakin tinggi aktivitas dan mikroorganisme, hal ini mengakibatkan semakin tinggi respirasi tanah.

\subsection{Analisis Prediksi Erosi}

Hasil prediksi erosi pada berbagai penggunaan lahan menunjukkan bahwa setiap penggunaan lahan yang berbeda memiliki nilai erosi yang berbeda. Pada Andisol berturut-turut indeks bahaya erosi mulai dari rendah hingga sangat tinggi (Tabel 3). Lahan hutan memiliki nilai erosi paling rendah $(0,2$ ton/ha/tahun), kemudian lahan kebun campuran (123,5 ton/ha/tahun), kebun teh (312 ton/ha/tahun), tegalan (387,7 ton/ha/tahun).

Penggunaan lahan hutan memiliki nilai erosi yang paling kecil dibandingkan penggunaan lahan yang lainnya. Rendahnya erosi yang terjadi pada suatu lahan dikarenakan 
peran vegetasi sebagai penutup lahan yang mampu melindungi tanah dari daya rusak butir hujan. Peran vegetasi dalam menghambat laju erosi adalah untuk mereduksi energi kinetik hujan sehingga kemampuanya untuk merusak struktur dan agregat tanah berkurang. Selain itu, vegetasi juga mampu mengendalikan aliran permukaan.

Tabel 3 Nilai Pendugaan Erosi Pada Setiap Penggunaan Lahan di Sub Sub DAS Cimanuk Hulu

\begin{tabular}{lrrr}
\hline $\begin{array}{c}\text { Penggunaan } \\
\text { Lahan }\end{array}$ & $\begin{array}{c}\text { Erosi } \\
\text { Potensial } \\
\text { (ton/ha } \\
\text { /tahun) }\end{array}$ & $\begin{array}{c}\text { Indeks } \\
\text { Bahaya } \\
\text { Erosi }\end{array}$ & Kriteria \\
\hline Hutan & 0,2 & 0,02 & Rendah \\
Tegalan & 387,7 & 35,24 & Sangat Tinggi \\
Kebun Teh & 312,0 & 28,36 & Sangat Tinggi \\
$\begin{array}{l}\text { Kebun } \\
\text { Campuran }\end{array}$ & 123,5 & 11,11 & Sangat Tinggi \\
\hline
\end{tabular}

Peran vegetasi dalam mengendalikan aliran permukaan dan erosi sangat dipengaruhi oleh sistem tajuk dan perakaran. Tajuk tanaman akan menahan daya tumbuk air hujan langsung ke tubuh tanah melalui daun, ranting dan batang. Sistem perakaran mampu meningkatkan laju infiltrasi dengan meningkatnya porositas. Serasah tanaman berperan ganda yaitu selain menahan tumbukan air hujan langsung ke tubuh tanah juga sebagai bahan organik yang memberikan porositas sehingga meningkatkan daya serap air ke tanah.

\subsection{Penilaian Kualitas Tanah}

Berdasarkan perhitungan indeks kualitas tanah dari beberapa parameter fisik, kimia dan biologi tanah maka diperoleh nilai rataan indeks kualitas tanah (Tabel 4). Penilaian kualitas tanah pada masing-masing penggunaan lahan menunjukkan bahwa hutan memiliki nilai paling tinggi, sedangkan tegalan memiliki nilai kualitas tanah paling rendah.

Berdasarkan hasil penilaian kualitas tanahnya, semakin rapat suatu vegetasi dan tan- pa pengolahan tanah akan semakin baik nilai kualitas tanahnya, dan semakin terbuka suatu lahan akan semakin rendah nilai kualitas tanahnya. Hutan adalah ekosisten alami yang sedikit mengalami gangguan oleh campur tangan manusia sehingga kondisi ekosistem serta unsur hara berada dalam kondisi yang baik. Sedangkan penggunaan lahan seperti tegalan ataupun kebun teh yang tidak terpelihara tidak mampu mempertahan-kan tingkat kualitas tanahnya.

Tabel 4 Rataan Indeks dan Peringkat Kualitas Tanah Andisol pada Berbagai Penggunaan Lahan di Sub Sub DAS Cimanuk Hulu

\begin{tabular}{lcc}
\hline Tutupan Lahan & $\begin{array}{c}\text { Skor Kualitas } \\
\text { tanah }\end{array}$ & Peringkat \\
\hline Hutan & 0,582 & 1 \\
Tegalan & 0,464 & 4 \\
Kebun Teh & 0,549 & 2 \\
Kebun Campuran & 0,516 & 3 \\
\hline
\end{tabular}

Baver et. al. (1976) menyatakan bahwa vegetasi memiliki sedikitnya empat fungsi yaitu: intersepsi hujan oleh kanopi tanaman, menurunkan kecepatan aliran permukaan, efek sistem perakaran terhadap peningkatan porositas, granulasi dan aktivitas biologi, serta transpirasi air saat musim kering.

Jenis vegetasi juga erat hubunganya dengan pengolahan lahan. Pengolahan ini merupakan campur tangan manusia dalam mengelola lahan untuk kebutuhan pangan, sandang dan papan. Pengolahan lahan mampu dapat berdampak baik atau buruk tergantung bagaimana manusia mengelola lahan tersebut. Karlen et. al. (1992) menyatakan bahwa faktor pengelolaan lahan mampu merubah kualitas tanah termasuk pengolahan tanah dan sisa tanaman serta rotasi tanaman. Pengolahan lahan lahan dalam waktu singkat nampaknya mampu merubah sifat fisik tanah menjadi kondisi yang lebih baik seperti peningkatan porositas dan laju infiltrasi tanah, namun dalam jangka waktu yang lama mampu memicu terjadinya erosi yang dicirikan de- 
ngan perubahan tekstur baik pada tempat terjadinya erosi ataupun lokasi deposisi.

Moges et. al. (2013) menyatakan bahwa terjadi peningkatan liat terjadi pada lahan pertanian dibandingkan padang rumput ataupun lahan hutan. Peningkatan liat diduga karena proses pengolahan lahan yang merubah regim kelembaban dan temperatur tanah. Peningkatan liat akan meningkatkan nilai bobot isi. Semakin tinggi bobot isi akan semakin rendah porositas, dan hal tersebut berpengaruh terhadap tata udara dan air tanah. tata air dan udara tanah akan baik jika kandungan bahan organik dalam tanah pun baik. Bahan organik memiliki peran yang sangat positif terhadap tanah dalam melindungi tanah terhadap kerusakan. Bahan organik yang berasal dari sisa tanaman, baik daun, batang dan akar merupakan salah satu sumber kelangsungan hidup bagi organisme tanah.

Perubahan kandungan bahan organik karena pengolahan tanah berlangsung dengan melibatkan proses kinetik biokimia yang dipengaruhi oleh iklim. Proses tersebut berupa penghancuran bahan organik setelah pengolahan tanah. Pengolahan tanah dapat menghancurkan makro dan mikro agregat, hal tersebut disayangkan karena menurut Mummey dan Stahl (2004) mikroagregat merupakan habitat dari mikroor-ganisme yang relatif lebih stabil daripada makroagregat di permukaan luar. Perubahan kadar bahan organik pada tanah mampu mempengaruhi stabilitas makroagregat (Lal, 1999).

Kandungan bahan organik tanah juga berpengaruh terhadap kandungan unsur hara. Karena salah satu fungsi bahan organik adalah membantu menyediakan unsur hara bagi tanaman. Kushawa et. al. (2000); Balota et. al. (2004) menyatakan bahwa dekomposisi bahan organik di permukaan mampu mempertahankan pencucian unsur hara pada profil tanah. Selain itu, faktor yang mempengaruhi kandungan unsur hara dapat disebabkan oleh sistem pertanaman, iklim dan pemberian pemupukan.
Menurut Randal dan Iragavarpu (1995) saat terjadi pengolahan tanah hancurnya agregat dan bahan organik juga meningkatkan pencucian terhadap unsur hara seperti $\mathrm{N}$. Pengolahan tanah konvensional mengakibatkan kehilangan $\mathrm{N}$ sebanyak $5 \%$ lebih tinggi daripada tanah yang tidak mengalami pengolahan. Keberadaan mikroorganisme juga mencerminkan kemampuan tanah dalam menyediakan unsur hara seperti (C,N,P dan S) serta kandungan bahan organik. Mikroorganisme juga memberikan respon saat kondisi tanah berubah.

\section{KESIMPULAN}

Penggunaan lahan memberikan pengaruh yang berbeda terhadap sifat fisik, kimia dan biologi tanah. Penggunaan lahan memberikan efek yang berbeda terhadap terjadinya erosi. Erosi paling tinggi terjadi pada lahan tegalan dan paling rendah pada lahan hutan. Terdapat perbedaan nilai kualitas tanah pada setiap penggunaan lahan. Nilai kualitas tanah paling tinggi pada penggunaan lahan hutan. Nilai kualitas tanah paling rendah pada tegalan.

\section{DAFTAR PUSTAKA}

Anwar, A. 1990. Beberapa konsepsi alokasi sumberdaya alam untuk penentuan kebijaksanaan ke arah pembangunan yang berkelanjutan. Makalah disampaikan pada Seminar Ilmu Tanah Indonesia. 9-10 Oktober 1990. Ujung Pandang.

Baver, L. D. 1976. Soil Physics. John Wiley \& Sons, Inc. New York

Karlen, D.L., M.J. Mausbach, J.W. Doran, R.G Cline, R.F. Harris and G.E. Schuman. 1996. Soil Quality: Concept, Rationale and Research Needs. Soil.Sci AmJ: 60, pp. 33-43.

Lal, R. 1999. Soil Quality and Soil Erosion. CRC Press: London.

Moges, Awdenegest, Melku D dan Fantaw Y. 2013. Land Use Effects on Soil Quality Indicators: A Case Study Abo-Wonsho 
Southern Ethiopia. Journal Applied and Environmental Soil Science Volume ID 784989. Hindawi Publishing Corporation. Ethiopia

Pratoyo. 2005. Analisis indeks kualitas tanah pertanian di lahan pesisir Pantai Samas Yogyakarta. Jurnal Ilmu Pertanian Vol 12(2), hal:140-150.

Rahasiani, R. 2014. Strategi Pengelolaan Sub DAS Cimanuk Hulu (Studi Kasus: Perubahan Tataguna Lahan Terhadap Debit Aliran dan Sedimentasi). Tesis. Universitas Padjadjaran. Bandung

Shoji, S., Masami, N. and Randy, D. 1993. Volcanic Ash Soils. Elsevier.
Netherland.

Sukarman dan Dariah, A. 2014. Tanah Andosol di Indonesia Karakteristik, Potensi, Kendala dan Pengolahanya untuk Pertanian. Balai Besar Penelitian dan Pengembangan Sumberdaya Lahan Pertanian. Bogor.

Wulaningsih, R.S. 2008. Studi Analisis Kualitas Tanah Pada Beberapa Penggunaan Lahan dan Hubunganya denan Tingkat Erosi di SUB DAS Keduang Kecamatan Jatisrono Wonogiri. Tesis. Program Pascasarjana Universitas Sebelas Maret. Surakarta. 